\title{
Tumor de células gigantes tenosinoviales
}

\section{Tenosynovial giant cell tumor}

Verónica Argüello Ramírez, * Héctor Mauricio Bazaldúa Cheda, ${ }^{\neq}$ José Alejandro Castillo García, ${ }^{\ddagger}$ María de Guadalupe Gómez Pérez ${ }^{\S}$

El tumor de células gigantes de la vaina tendinosa (TCGVT) es el prototipo y la neoplasia benigna más común que se deriva de la vaina tendinosa o del tejido sinovial. ${ }^{1,2}$ Fue descrito por primera vez en 1852 por Chassaignac. ${ }^{1}$ Éste tiene una forma localizada y otra difusa. La topografía más frecuente de la primera son los dedos cerca de las articulaciones interfalángicas, la mano y la muñeca; la forma difusa ocurre en áreas adyacentes a articulaciones que soportan peso, como son: pie, tobillo, rodilla y cadera, ${ }^{3}$ siendo de comportamiento más agresivo y con un mayor índice de recurrencias.

Femenino de 53 años, quien inició su padecimiento actual hace meses, el cual se caracteriza por la presencia de una neoformación subcutánea y lobulada, localizada en la
Figura 1:

Resonancia magnética mutiplanar de la mano izquierda. A) Corte coronal T1 en el cual se documenta una lesión ocupativa de bordes irregulares que se localiza a nivel de la articulación interfalángica proximal del dedo anular. B) Corte axial T1 que muestra pequeñas imágenes con ausencia de señal en su interior. C y D) Corte axial y sagital T2 con saturación grasa,

la cual muestra intensidad de señal heterogénea incrementada y estrecha relación con el tendón flexor. E) Corte sagital T1 + Gd que muestra un realce heterogéneo de la lesión.
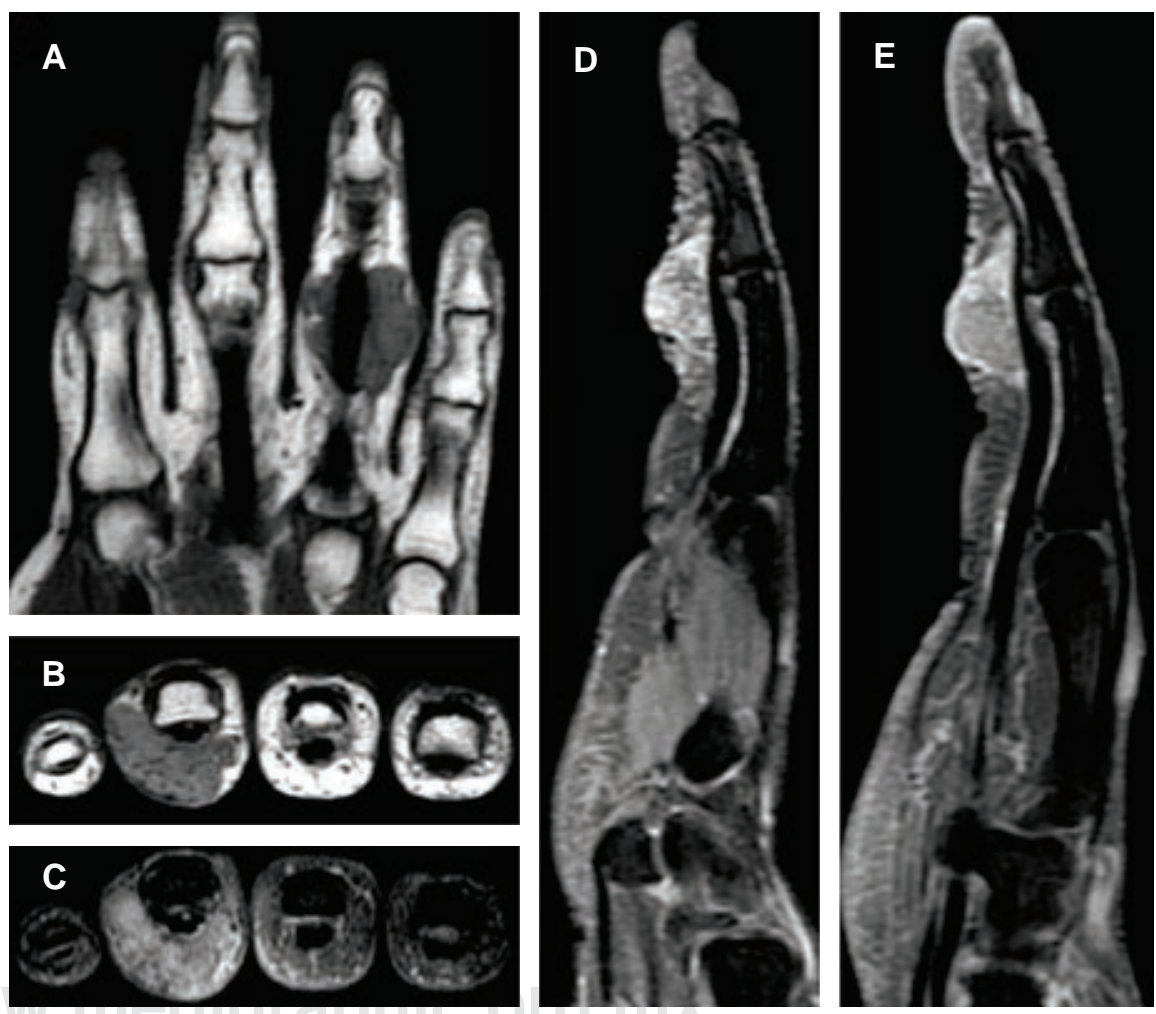

* Médico residente del Curso de Alta Especialidad en Resonancia Magnética del Cuerpo Completo. Facultad de Medicina de la UNAM.

₹ Médico residente del Curso de Alta Especialidad en Resonancia Magnética del Sistema Musculoesquelético. Facultad de Medicina de la UNAM.

$\S$ Jefe del Servicio de Resonancia Magnética.

Hospital Ángeles Pedregal.
Correspondencia:

Dra. Verónica Argüello Ramírez

Correo electrónico: ramirez961202@yahoo.com.mx

Aceptado: 11-12-2020.

www.medigraphic.com/actamedica

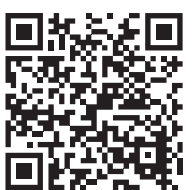


articulación interfalángica del dedo anular. Esta formación se ha incrementado de tamaño en las últimas semanas, y a la palpación, es de consistencia dura, lo que da la impresión de estar fija a los planos profundos, siendo de evolución crónica y asintomática.

La resonancia magnética contrastada demostró una lesión ocupativa de espacio, la cual estaba localizada en los tejidos blandos superficiales y profundos del dedo anular a nivel de la articulación interfalángica proximal, que sigue el trayecto del tendón flexor del dedo anular, que se comportó isointensamente respecto a los tejidos blandos en el T1 y T2 y se incrementó su señal de manera heterogénea en la saturación grasa. Además, se evidenció un realce con la aplicación del medio de contraste, cuyos diámetros apro- ximados en el plano coronal fueron de $2 \mathrm{~cm}$ de longitud por $1.9 \mathrm{~cm}$ de diámetro transverso. Asimismo, presentó en su interior pequeñas imágenes que muestran ausencia de señal, probablemente relacionadas con depósitos de hemosiderina (Figura 1).

\section{REFERENCIAS}

1. Ozben H, Coskun T. Giant cell tumor of tendon sheath in the hand: analysis of risk factors for recurrence in 50 cases. BMC Musculoskelet Disord. 2019; 20: 457.

2. Di Grazia S. Giant cell tumor of tendon sheath: study of 64 cases and review of literature. G Chir. 2013; 34: 149-152.

3. Enríquez J, Flores CM, De Alba L, Alcalá PD. Tumor de la vaina tendinosa. Reporte de un caso y revisión de la literatura. Rev Cent Dermatol Pascua. 2000; 9 (2): 102-104. 